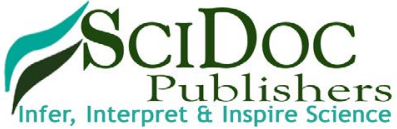

International Journal of HIV/AIDS and Research (IJHR)

ISSN 2379-1586

\title{
Knowledge and Practices of Male Circumcision as an HIV/AIDS Prevention Measure among Males in Mbarara Municipality
}

Research Article

\author{
Moses $\mathrm{A}^{1 *}$, Patience $\mathrm{K}^{2}$, Christopher $\mathrm{K}^{3}$ \\ ${ }^{1}$ Department of Nursing, Mountains of the Moon University, Uganda. \\ ${ }^{2}$ Fertility Centre, Bethany Women's Hospital, Uganda. \\ ${ }^{3}$ Population Services International, Uganda.
}

\section{Abstract}

Since the beginning of the HIV/AIDS epidemic in the 1980's, more than 60 million people have acquired the Human Immunodeficiency Virus and AIDS related illnesses have claimed nearly 20 million lives worldwide. The landmark randomized clinical trials (RCT) conducted in Orange Farm in South Africa, Rakai district in Uganda, Kisumu province in Kenya (demonstrated a reduction in HIV incidence among circumcised men. Uganda incorporated Medical Male Circumcision into the HIV prevention package in 2009 to enable improved provision of MC services in Uganda. This study mainly assessed the knowledge, attitudes and practices of Male Circumcision as an HIV/AIDS prevention measure among males in Mbarara Municipality.

This cross-sectional study was conducted in July 2017 among 150 males aged between 18-49 years at Kamukuzi, Kakoba and Nyamitanga health centers in Mbarara municipality in Uganda.

The study found that $58 \%$ of the respondents were circumcised. Respondents reported good knowledge on the benefits of male circumcision on HIV infection. For example, $86 \%$ of the respondents revealed that Circumcision of an HIV negative man reduces HIV risk. Majority of the respondents had positive attitudes towards male circumcision which could possibly explain the high prevalence of circumcision (58\%). In fact, $43.3 \%$ and $70.7 \%$ revealed that circumcised men enjoy sex more than uncircumcised men and would recommend MC to their sons respectively.

From this study, a high level of knowledge was found, particularly its potential to reduce the risk of HIV infection. Similarly, the respondents had good attitudes towards Male circumcision. Male Circirmcision is accepted on a large scale by males in Mbarara municipality as an HIV prevention strategy considering that this is not a traditionally circumcising community.

Keywords: Circumcision; Prevention; Knowledge; Attitudes; Practices.

Abbreviations: ART: Antiretroviral Therapy; DHS: Demographic Health Survey; GUD: Genitourinary Disease; HIV: Human Immunodeficiency Virus; MARPs: Most-At-Risk Populations; MC: Male Circumcision; MMC: Medical Male Circumcision; MoH: Ministry of Health; PITC: Provider Initiative Testing and Counseling; RCTs: Randomized Controlled Trials; STDs: Sexually Transmitted Diseases; UAIS: Uganda AIDS Indicator Survey; UDHS: Uganda Demographic Health Survey; UNAIDS: United Nations Joint Programme on AIDS; WHO: World Health Organization.

\section{Introduction}

Male circumcision is the surgical removal of all or part of the fore skin from the penis [1]. Circumcision is one of the prehistoric, oldest and largely widespread surgical procedures ever practiced
[2]. Recently, male circumcision has been rolled out as one of the HIV/AIDS prevention strategies especially in non-circumcising communities. Its roll-out follows several randomized clinical trials that concluded that MC reduces the chances of HIV transmission through heterosexual intercourse. The landmark randomized

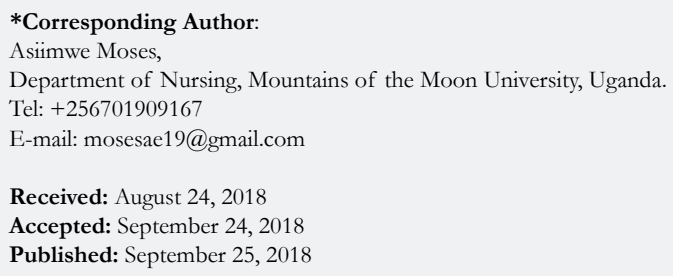

Copyright: Moses $\mathbf{A}^{\circ}$ 2018. This is an open-access article distributed under the terms of the Creative Commons Attribution License, which permits unrestricted use, distribution and reproduction in any medium, provided the original author and source are credited. 
clinical trials (RCT) conducted in Orange Farm in South Africa [3], Rakai district in Uganda [4], Kisumu province in Kenya [5] demonstrated a reduction in HIV incidence among circumcised men. Uganda incorporated Medical Male Circumcision into the HIV prevention package in 2010 to enable improved provision of MC services in Uganda [6].

Since the inception of the epidemic, more than 60 million people have acquired the Human Immunodeficiency Virus (HIV) and Acquired Immunodeficiency Syndrome (AIDS) related illnesses have claimed nearly 20 million lives [7]. Amid intense and continued reaction to the pandemic, HIV continues to spread; causing more than 14000 new infections everyday and 95\% of these occur in the developing world [7]. To date, AIDS is the leading cause of death in Africa and the fourth worldwide [7].

\section{Male Circumcision in Uganda}

Uganda is one of the first countries in the Sub-Saharan Africa to experience the devastating impact of HIV/AIDS and to take action to control the epidemic [8]. It is among the least developed countries situated in the Great Lakes region of East Africa and is composed of several districts [9]. The adult HIV/AIDS prevalence in 2016 was estimated at an average of $6 \%$ and that about 1.3 million adults were living with HIV yet, an estimated 28,000 deaths were attributed to AIDS [10], Sexual transmission contributing $76 \%$ of new HIV infections while Mother to Child Transmission contributes $22 \%$ [11].

In 2010, the government of Uganda through the ministry of health in collaboration with key stakeholders announced a Safe Male Circumcision Policy. This in accordance to a recommendation from the World Health Organisation (WHO) and the United Nations program on HIV/AIDS (UNAIDS) was to reach and achieve $80 \%$ safe male circumcision coverage among 15-49 year old males [6, 14].

Furthermore, there is evidence to suggest that despite a significant decline in HIV prevalence between 1992 and 2002, HIV prevalence has stagnated over the last 5-11years at between 6.1 and $7.0 \%$ and may be raising in some parts of the country or specific population groups [12]. Women, urban dwellers and residences of the past conflict northern region are more affected. In response to the HIV/AIDS epidemic, the government of Uganda instituted preventive and therapeutic measures to help curb the spread of HIV and AIDS [13]. HIV prevention strategies comprised of both behavioral and biomedical strategies. These included voluntary counseling and testing, Abstinence, being Faithful to one partner and the use of Condoms.

\section{Male Circumcision and HIV Infection}

Circumcision is one of the prehistoric and largely widespread surgical procedures ever practiced $[2,16]$. Circumcision has been by tradition conducted for an assortment of reasons such as hygiene, medical, religion and ethnicity $[1,17]$. Doyle, 2005 quotes that in the majority of cultures; male circumcision is a symbol of manhood connected with bravery and endurance. Furthermore, it is also associated with masculinity, social cohesion, self-identity and spirituality $[18,19]$.
Though being an ancient practice [19], estimated that worldwide, only $30 \%$ of the males aged 15years and above are circumcised where approximately $69 \%$ are Muslim, $0.8 \%$ are Jewish and 13\% are non-Muslim and Jewish men living in the United States of America [19]. Studies indicate that about $26 \%$ of African males are circumcised overall and this rate differs within countries, regions, ethnic and religious groups [20]. For instance, in Kenya $84 \%$ of the men are circumcised, yet, the percentage is much lower for the Luo and Turkana ethnic tribes with $17 \%$ and $40 \%$ respectively [21].

The advent of the HIV/AIDS epidemic in the 1980's prompted researchers to explore the correlation between MC and HIV infection [22]. In 1986 Fink published a paper that suggested the protective effect of MC against HIV infection [3]. Since then, various epidemiological studies have documented a significant protective effect of MC against HIV infection and other sexually transmitted infections (STIs) in men [23-25].

Over 40 observational studies and one clinical trial have found that male circumcision (MC) has a protective effect against HIV acquisition of between $40 \%$ and $88 \%$ [26]. Evidence suggests that circumcision reduces the risk of becoming infected with HIV through heterosexual intercourse by at least one-half, and possibly as much as two thirds [27]. The landmark randomized clinical trials (RCT) conducted in Orange Farm in South Africa [3], Rakai district in Uganda [4], Kisumu province in Kenya [5] demonstrated a reduction in HIV incidence among circumcised men. These findings, which supplemented results from earlier observational studies, demonstrated that male circumcision has the potential to sharply reduce HIV infection rates. Moreover, biological studies of the foreskin have indicated that a high concentration of stratified squamous epithelial cells of the foreskin are very susceptible to HIV-1 infection [27], which is one of the possible biological validation as to why circumcision may reduce HIV acquisition.

It is believed that uncircumcised men have a greater susceptibility to HIV due to biological properties of the inner foreskin which contains a high concentration of Langerhans cells and other HIV target cells near the surface of the epithelium where there is no or minimal keratin protection [28]. Furthermore, circumcision leads to a decrease in STI's and a possible reduction in micro tears and trauma to the foreskin during sex [29]. Based on the experimental substantiation, MC could have a considerable impact on the HIV epidemic especially among the most highly affected countries [30]. In fact, models have estimated that routine MC in Sub-Saharan Africa could highly avert about 6 million new infections and 3 million deaths in the next two decades [20].

Although studies have shown the effectiveness of male circumcision in reducing HIV transmission in heterosexual contact, there are concerns over attitudes, perceptions and utilization hence affecting the acceptability rates. Atashili (2006) noted that the stigma associated with circumcision, fear of pain and bleeding, reduced libido and unavailability of medical male circumcision services have the potential to hinder the successful implementation of interventions. Studies conducted in South Africa [31-33] reported acceptability rates of $51-61 \%$ in uncircumcised men. Likewise, a review carried out by Westercamp and Bailey (2007) to establish the acceptability of MC for prevention of HIV infections in non-circumcising societies in 
Eastern and Southern Africa, revealed that the median proportion of uncircumcised men willing to become circumcised was $65 \%$, ranging from $29 \%$ in Uganda to $81 \%$ and $87 \%$ in Swaziland and Botswana respectively.

\section{Objectives of the Study}

- To determine the level of knowledge regarding MC among males in Mbarara municipality.

- To determine the level of practice of MC as an HIV/AIDS prevention measure among males in Mbarara municipality.

\section{Materials and Methods}

\section{Area of the Study}

The study was conducted in Mbarara Municipality. This is one of the 22 municipalities in Uganda and has a population of 195,500 inhabitants [34] and the largest business center and administrative center in Mbarara district. Mbarara municipality is bordered by Rwampara County in the west, Kashari County in north and east then Isingiro district in south. It is comprised of three divisions which include Kakoba, Kamukuzi and Nyamitanga; six wards and fifty two cells. The study was conducted at Kakoba, Nyamitanga and kamukuzi health centres found in Mbarara town along which are the three major facilities in the town.

\section{Study Design}

A cross-sectional descriptive technique was used during the collection of data from the research participants. Moreover, the design employed quantitative methodologies to quantify the data. This allowed the researcher to get information and determine the individuals' knowledge, attitudes, practices and barriers about MC [35]. A cross-sectional design was important and most appropriate since the study assessed the variables in a specific period of time (may-June 2017).

\section{Study Population}

The study population comprised of all men residing in the municipality between ages of 18 and 49 years attending health care services at major health centers in the municipality because this provided a number of respondents from all divisions thus a representative of the general population of males in Mbarara municipality.

The study targeted all males aged between 18-49 years of age who had resided within the municipality for more than five months.

\section{Sampling Method}

The researchers used a purposive sampling method to select both the health centres and the respondents. This method was used because it enabled selecting individuals to participate in the study basing on the fact that they were males in the study area who would give the most relevant information regarding knowledge, attitudes and perceptions of male circumcision as an HIV prevention measure. The three facilities were selected basing on the fact that they largest health facilities in their respective municipal divisions.

\section{Sample Size}

A sample size was derived using the Kish Leslie Formula of sample size calculation [36].

$\mathrm{n}=\mathrm{z}^{2} \mathrm{pq} / \mathrm{d}^{2}$

Therefore total of 150 respondents participated in the study.

\section{Data Collection Tools}

A pre-determined questionnaire was used to collect data from research participants. Therefore a questionnaire with closedended questions was issued to research participants to collect data through self-report.

\section{Validity}

To ensure validity, the questionnaire was maintained in English to avoid errors which would arise during translation. Therefore translation was done during interpretation of questions to those who would not understand English. Besides, the questionnaire was pretested to address any ambiguities prior to the data collection process. Furthermore, external validity which is concerned with the application of the study findings to the real world [37] was also ensured. External validity is in fact, an issue of generalizability. The findings of this study can only be generalized to the males in the Mbarara municipality.

\section{Inclusion Criteria}

All males who had resided in the study area for at least five months and above.

* All males aged 18-49 years at the time of the study in the municipality.

* Males who will consent for the study.

\section{Exclusion Criteria}

* All males who would not consent for the study.

* All males who were less than 18 or above 49 years of age.

* All males who lived in Mbarara municipality for less than five months.

\section{Ethical Considerations}

- To reinforce voluntary participation, participants were required to complete a consent form (Appendix 2). Issues of confidentiality, respect and anonymity were explained and emphasized.

- Permission to conduct the study was sought in a series of department offices including the department of Nursing and Midwifery, the municipal town clerk of Mbarara municipality who is the area accounting officer as well as the heads of health facilities where the study was conducted.

- Participant's identity was kept confidential since the questionnaires did not request participants to reveal their identity. Records of the survey and the consent forms were kept in a safe and private place.

\section{Data Analysis}

The researcher started the process by systematically organizing 
the raw material encountered during data collection. Raw data is usually unordered, contains errors and missing data, these were transformed into an ordered error free data before analysis. Thus, the data was prepared in three tasks of: coding, entering and cleaning and data were analyzed using the Microsoft Excel program.

\section{Dissemination of Data}

Dissemination of study findings is important to provide knowledge from research to the general population. Findings from this study were documented in copies of research dissertation were, Mbarara municipal public library, as well as the Office of the municipal Principal Medical Officer.

\section{Description of Study Sample}

A total of 150 males were approached and agreed to participate in the study yielding a response rate of $100 \%$. All males who participated in the study responded to all the questions in the questionnaire. All 150 questionnaires were included in the analysis.

\section{Results}

\section{Socio-demographic characteristics of study population}

Table 1.

\section{Prevalence of male circumcision}

Table 2.

\section{Reasons for circumcision}

Table 3.

\section{Comparison of Circumcised and Uncircumcised respondents by Socio-demographic characteristics}

In order to identify whether there are socio-demographic differences between circumcised and uncircumcised males, the study assessed whether demographic characteristics differed according to MC status of the respondents in the study. Age, marital status, level of education and religion were each compared to circumcision status.

Majority of males who were circumcised (51.1\%) were aged between $18-25$ years and $54.5 \%$ were single or never married Table 4.

Respondents' knowledge of MC and related health aspects

Circumcision of a man with HIV does not protect partner from getting HIV.

Table 1. Socio-demographic characteristics.

\begin{tabular}{|c|c|c|}
\hline Characteristic & Frequency & Percentage \\
\hline $\begin{array}{c}\text { Age } \\
18-25 \\
26-32 \\
33-40 \\
41-49\end{array}$ & $\begin{array}{l}72 \\
35 \\
26 \\
17\end{array}$ & $\begin{array}{c}48 \\
23.3 \\
17.3 \\
11.3\end{array}$ \\
\hline $\begin{array}{c}\text { Marital status } \\
\text { Single, never married } \\
\text { Married } \\
\text { Divorced or separated } \\
\text { Widowed }\end{array}$ & $\begin{array}{c}71 \\
67 \\
6 \\
6\end{array}$ & $\begin{array}{c}47.3 \\
44.7 \\
4 \\
4\end{array}$ \\
\hline $\begin{array}{c}\text { Level of education } \\
\text { None } \\
\text { Primary } \\
\text { Secondary } \\
\text { Advanced level } \\
\text { Tertiary }\end{array}$ & $\begin{array}{c}6 \\
28 \\
41 \\
38 \\
37\end{array}$ & $\begin{array}{c}4 \\
18.7 \\
27.3 \\
25.3 \\
24.7\end{array}$ \\
\hline $\begin{array}{l}\text { Religion } \\
\text { None } \\
\text { Anglican } \\
\text { Catholic } \\
\text { Muslim } \\
\text { Other }\end{array}$ & $\begin{array}{c}0 \\
59 \\
39 \\
21 \\
31\end{array}$ & $\begin{array}{c}0 \\
39.3 \\
26 \\
14 \\
20.7\end{array}$ \\
\hline $\begin{array}{c}\text { Language spoken } \\
\text { Rukiga } \\
\text { Runyankole } \\
\text { English } \\
\text { Other }\end{array}$ & $\begin{array}{c}47 \\
85 \\
1 \\
16\end{array}$ & $\begin{array}{c}31.3 \\
56.7 \\
0.7 \\
10.7\end{array}$ \\
\hline Total & 150 & 100 \\
\hline
\end{tabular}

Source: Field data; July, 2017

Table1 presents demographic characteristics of the respondents in the study. The majority, 72 (48\%) of the respondents were aged between 18 to 25 years. 
Table 2. MC prevalence.

\begin{tabular}{|c|c|c|}
\hline Response & Frequency & Percentage \\
\hline Yes & 88 & 58 \\
\hline No & 62 & 43 \\
\hline Total & 150 & 100 \\
\hline
\end{tabular}

Source: Field data; July, 2017

Among all the respondents, $88(58 \%)$ reported that they were circumcised.

Table 3. Reasons for wanting to be circumcised.

\begin{tabular}{|c|c|c|c|c|c|c|c|c|c|c|}
\hline \multirow{2}{*}{ Age } & \multicolumn{2}{|c|}{ Prevent HIV } & \multicolumn{2}{|c|}{ Religious } & \multicolumn{2}{c|}{ Health reasons } & \multicolumn{2}{|c|}{ Culture } & \multicolumn{2}{|c|}{ Others } \\
\cline { 2 - 12 } & $\mathbf{n}$ & $\mathbf{\%}$ & $\mathbf{n}$ & $\mathbf{\%}$ & $\mathbf{n}$ & $\mathbf{\%}$ & $\mathbf{n}$ & $\mathbf{\%}$ & $\mathbf{n}$ & $\mathbf{\%}$ \\
\hline $18-25$ & 25 & 55.5 & 8 & 17.8 & 8 & 17.8 & 0 & 0.0 & 4 & 8.9 \\
\hline $26-32$ & 14 & 63.7 & 5 & 22.7 & 1 & 4.5 & 0 & 0.0 & 2 & 9.1 \\
\hline $33-40$ & 8 & 57.1 & 2 & 14.2 & 4 & 28.6 & 0 & 0.0 & 0 & 0.0 \\
\hline $41-49$ & 4 & 57.1 & 2 & 28.6 & 1 & 14.3 & 0 & 0.0 & 0 & 0.0 \\
\hline Total & 51 & $(57.95 \%)$ & 17 & $(19.3 \%)$ & 14 & $(15.9 \%)$ & 0 & $(0.0 \%)$ & 6 & $(6.8 \%)$ \\
\hline
\end{tabular}

Source: Field data; July, 2017

Among 88 respondents who were circumcised, 51(57.95\%) circumcisions were performed to prevent HIV.

Table 5, 6.

\section{Respondents' willingness to be circumcised}

Figure 1.

The graph above indicates that among sixty two uncircumcised respondents, $30(48.4 \%)$ reported that they would like to be safely circumcised if circumcision reduces the chance of HIV infections.

\section{Figure 2.}

This question required respondents to choose one or more options to answer. Of 88 respondents who reported that they were circumcised, at least $58(38.7 \%)$ respondents cited prevention of HIV. Other reasons included religion, partner's desire, culture, sexual pleasure and other health reasons.

\section{Recommendation of MC to male child}

Table 6 .

\section{Discussion}

\section{Knowledge of Male Circumcision}

Respondents reported good knowledge on the benefits of MC on HIV infection, STI prevention as well as penile hygiene. For example, eighty-six percent of the respondents revealed that circumcision of an HIV negative man reduces HIV risk (Table 5). This was explained by the fact that the municipality had a vast number of communication networks such as televisions, radios and billboards as well as health facilities which were important in information dissemination. Access to these networks was significantly associated with knowledge about MC in HIV prevention [38]. In fact, most respondents received information on male circumcision from the media and health workers (Table 6). The study found out that the more the level of knowledge, the higher the chances of practicing (Table 5), for example, $63.7 \%$ of those who agreed that circumcision reduces the chances of getting HIV were actually circumcised. Similarly, Tarimo et al., (2012) revealed in his study that the participants were knowledgeable about the benefits of circumcision on penile hygiene and its contribution to STI prevention and emphasis was placed on HIV prevention. Moreover, the findings presented above are supported by Chikutsa (2011) who noted that the knowledge of MC as an HIV prevention intervention was high.

Contrary, only a few respondents were not fully aware of the health benefits of Male circumcision. Therefore further information dissemination is needed in the municipality. Furthermore, not all those who were knowledgeable were circumcised. This suggests that although the respondents are knowledgeable about the benefits of MC on HIV infection and STI prevention and penile hygiene, barriers such as fear of pain stalled the practice of MC (Table 7).

The awareness of MC may be attributed to the trials which were conducted in South Africa, Kenya and Uganda on MC and HIV infection association [3-5] and the recent announcement by the Ugandan government to embark on the introduction of safe MC to the public as outlined in the 2nd National Health Policy. Halperin et al., (2005) reported that level of knowledge was linked with increased rates of circumcision particularly among noncircumcising communities. This might be explained by the fact that circumcision is becoming more publicized and acceptable even among those communities where male circumcision is not part of their tradition such as Mbarara district.

\section{Practice of Male Circumcision}

Male circumcision is more common among urban men than rural 
Table 4. MC status by socio-demographic characteristics.

\begin{tabular}{|c|c|c|c|}
\hline Characteristic & $\begin{array}{c}\text { Circumcised } \\
\mathbf{n = 8 8}\end{array}$ & $\begin{array}{c}\text { Uncircumcised } \\
\mathbf{n = 6 2}\end{array}$ & $\begin{array}{c}\text { Total } \\
\mathbf{n}=\mathbf{1 5 0}\end{array}$ \\
\hline Age & & & \\
$18-25$ & $45(51.1 \%)$ & $27(43.5 \%)$ & $72(48 \%)$ \\
$26-32$ & $22(25 \%)$ & $13(20.96 \%)$ & $35(23.3 \%)$ \\
$33-40$ & $14(15.9 \%)$ & $12(19.4 \%)$ & $26(17.3 \%)$ \\
$41-49$ & $7(7.95 \%)$ & $10(16.1 \%)$ & $17(11.3 \%)$ \\
\hline Marital status & & & \\
Single, never married & $48(54.5 \%)$ & $23(37.1 \%)$ & $71(47.3 \%)$ \\
Married & $32(36.5 \%)$ & $35(56.45 \%)$ & $67(44.7 \%)$ \\
Divorced or separated & $5(5 \%)$ & $2(3.2 \%)$ & $6(4 \%)$ \\
Widowed & $3(4 \%)$ & $2(3.2 \%)$ & $6(4 \%)$ \\
\hline Level of education & & & \\
None & $3(3 \%)$ & $7(11 \%)$ & $10(6.6 \%)$ \\
Primary & $14(15.9 \%)$ & $10(16 \%)$ & $24(16 \%)$ \\
Secondary & $29(33 \%)$ & $13(20.96 \%)$ & $41(27.3 \%)$ \\
Advanced level & $20(22.7 \%)$ & $18(29.03 \%)$ & $38(25.3 \%)$ \\
Tertiary & $22(25 \%)$ & $15(24.2 \%)$ & $37(24.7 \%)$ \\
\hline Religion & & & \\
None & $0(0 \%)$ & $0(0 \%)$ & $0(0 \%)$ \\
Anglican & $33(37.5 \%)$ & $22(35.4 \%)$ & $55(36.6 \%)$ \\
Catholic & $23(26.1 \%)$ & $20(32.3 \%)$ & $43(28.6 \%)$ \\
Muslim & $21(23.9 \%)$ & $0(0 \%)$ & $21(14 \%)$ \\
Other & $11(12.5 \%)$ & $20(32.3 \%)$ & $31(20.7 \%)$ \\
\hline & & & \\
\hline
\end{tabular}

Source: Field data; July, 2017

Majority of males who were circumcised (51.1\%) were aged between $18-25$ years and $54.5 \%$ were single or never married.

Table 5. Knowledge of MC and related health aspects.

\begin{tabular}{|c|c|c|c|c|}
\hline Responses & $\begin{array}{c}\text { Circumcised } \\
\mathbf{N}=\mathbf{8 8}\end{array}$ & $\begin{array}{c}\text { Uncircumcised } \\
\mathbf{N = 6 2}\end{array}$ & $\begin{array}{c}\text { Frequency } \\
(\mathbf{N = 1 5 0})\end{array}$ & $\begin{array}{c}\text { Percentage } \\
(\mathbf{\%}=\mathbf{1 0 0})\end{array}$ \\
\hline Circumcision reduces chances of getting HIV & & & & \\
True & 82 & 47 & 129 & 86 \\
False & 2 & 6 & 8 & 5.3 \\
Not sure & 4 & 9 & 13 & 8.7 \\
\hline MC does not completely remove chances of getting & & & & \\
HIV & & & & \\
True & 81 & 45 & 126 & 84 \\
False & 1 & 5 & 6 & 4 \\
Not sure & 6 & 12 & 18 & 12 \\
\hline True & 1 & 1 & & \\
False & 70 & 45 & 115 & 7.3 \\
Not sure & 15 & 18 & 33 & 22 \\
\hline No chance of a circumcised man getting HIV & & & & \\
Frue & 63 & 39 & 102 & 68 \\
False & 9 & 8 & 17 & 11.3 \\
Not sure & 13 & 18 & 31 & 20.7 \\
\hline Circumcision reduces the risk of other STIs & & &
\end{tabular}

Source: Field data; July, 2017

Nearly all respondents $129(86 \%)$ agreed that circumcision reduces chances of getting HIV. 
Table 6. Other related health aspects.

\begin{tabular}{|c|c|c|}
\hline Response & Frequency & Percentage \\
\hline True & 107 & 71.3 \\
\hline False & 15 & 10 \\
\hline Not sure & 28 & 18.7 \\
\hline Total & 150 & 100 \\
\hline
\end{tabular}

Source: Field data; July, 2017

A high percentage of respondents $(71.3 \%)$ concurred that circumcision does not protect partner from getting HIV.

Figure 1. Respondents' willingness to be circumcised.

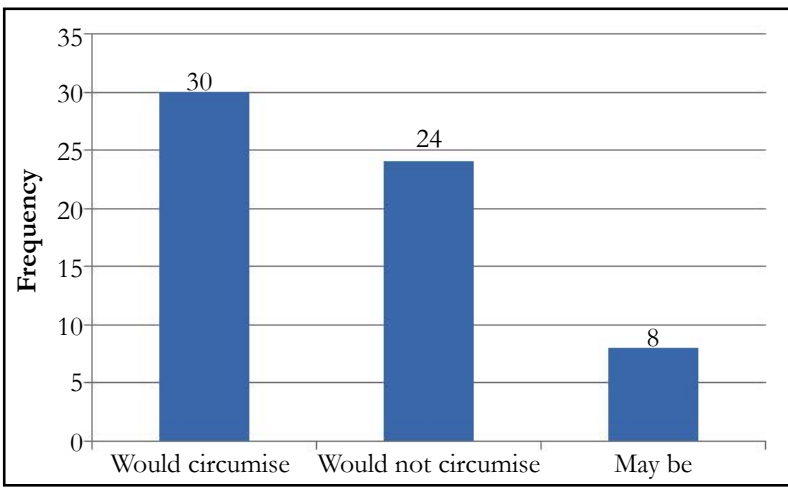

Source: Field data; July, 2017

Figure 2. Reason for wanting to be circumcised.

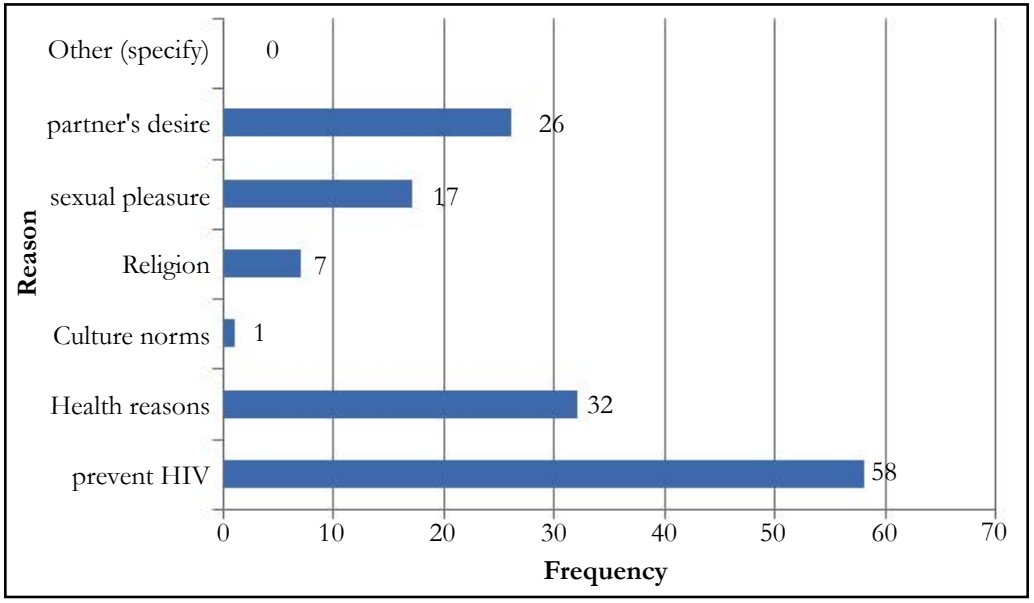

Source: Field data; July, 2017

Table 7. Males who would recommend MC to child.

\begin{tabular}{|c|c|c|}
\hline Response & Frequency & Percentage \\
\hline Yes & 106 & 70.7 \\
\hline May be & 24 & 16 \\
\hline No & 20 & 13.3 \\
\hline
\end{tabular}

Source: Field data; July, 2017

According to the table above, more than half of the respondents (70.7\%) revealed that they would actually recommend Male Circumcision to their children or any young males. 
men by $37 \%$ and $24 \%$ respectively [14]. Similarly, this study found out that $58.7 \%$ were circumcised. The possible explanation of a higher MC prevalence was the fact that people had a high level of knowledge about $\mathrm{MC}$ and the fact that respondents reported availability of the services of $\mathrm{MC}$ in the municipality in several medical centers and hospitals. It was also much more common among males between $18-25$ years (51.1\%); single, never married males (Table 4). This age group is more sexually active (Singh S et al., 2003) thus the fear to contract HIV (38.7\%) while others $(17.3 \%)$ reported to be convinced by their sexual partners (Figure 2).

The prevalence of MC in this study was higher than the national average MC among urban males of 37\% [14]. This may be partly explained by the fact that Mbarara municipality has a variety of health care facilities providing MC services and a number of organizations providing free circumcision services to the people in the municipality [14].

Circumcision may be conducted at health facilities by trained personnel or by religious or traditional circumcisers whose methods and experience differ [16]. The study revealed that $80.7 \%$ of respondents were circumcised by health workers and $19.3 \%$ by traditional circumcisers. This finding reveals that the National Circumcision policy of conducting circumcision procedure has been adopted by the males in Mbarara municipality.

The current study revealed that HIV prevention, health reasons (hygiene, STI prevention, surgical conditions) and partner's desire were the major contributing factors for considering MC among all respondents. This is because Mbarara municipality is not a traditional circumcising community and thus all MC campaign recommend HIV, STI prevention as well as penile hygiene. Moreover, a Kenyan study revealed that the two principal reasons favoring male circumcision were reduced risk of STD/HIV infection [32].

Despite being conscious about facilities providing MC, respondents revealed that there are factors that hinder them to access male circumcision services. These included not having time away from work, cultural and religious values, and fear of pain, the cost and transport and temporally availability of services. These findings concur with a previous study conducted by [39] who noted that fear of pain, lack of time, fear of complications and religious reasons were among the most cited barriers to MC.

\section{Study limitations}

This study relied on self reports on circumcision status amongst respondents. However, 4-7\% self-reports on circumcision have not been found to be precise [41]. Since no clinical examinations were performed during the interview to confirm the circumcision status, results on the circumcision prevalence rate reported in this study should be interpreted cautiously.

\section{Conclusion}

This study sought to assess knowledge, attitudes and practices of male circumcision as an HIV prevention measure among males in Mbarara municipality. A high level of knowledge was found; particularly its potential to reduce the risk of HIV infection.
Similarly, the respondents had good attitudes towards Male circumcision. MC is accepted on a large scale by males in Mbarara municipality as an HIV prevention strategy. Despite the high level of knowledge and positive attitudes, barriers to safe MC still exist and these have hindered its uptake. The study findings would be useful to health policy makers in Mbarara Municipality in making and implementing MC intervention programmes.

\section{Recommendations}

Taking these study findings into account, the following recommendations are proposed.

1. There is need to recognize the need for more sufficient education with emphasis that safe MC does not provide total protection against HIV.

2. The traditionally circumcising groups of people such as Muslims should be encouraged to undergo circumcision from a health facility by a skilled health worker to minimise the chances of developing complications.

3. The government and policy makers should also emphasize safe MC for older males since few of them are circumcised.

4. Policy makers should formulate policies and interventions that focus on eliminating barriers of $\mathrm{MC}$ as an HIV prevention measure.

\section{References}

[1]. Van Dam J, Anastasi MC. Male Circumcision and HIV Prevention: Directions for Future Research. Alabama: USAID; 2000.

[2]. Auvert B, Sobngwi-Tambekou J, Cutler E, Nieuwoudt M, Lissouba P, Puren A, et al. Effect of male circumcision on the prevalence of high-risk human papillomavirus in young men: results of a randomized controlled trial conducted in Orange Farm, South Africa. J Infect Dis. 2009 Jan 1;199(1):14-9. doi: 10.1086/595566. PubMed PMID: 19086814.

[3]. Auvert B, Taljaard D, Lagarde E, Sobngwi-Tambekou J, Sitta R, Puren A. Randomized, controlled intervention trial of male circumcision for reduction of HIV infection risk: the ANRS 1265 Trial. PLoS Med. 2005 Nov;2(11):e298. PubMed PMID: 16231970.

[4]. Gray RH, Kigozi G, Serwadda D, Makumbi F, Watya S, Nalugoda F, et al. Male circumcision for HIV prevention in men in Rakai, Uganda: a randomised trial. Lancet. 2007 Feb 24;369(9562):657-66. PubMed PMID: 17321311.

[5]. Bailey RC, Moses S, Parker CB, Agot K, Maclean I, Krieger JN, et al. Male circumcision for HIV prevention in young men in Kisumu, Kenya: a randomised controlled trial. Lancet. 2007 Feb 24;369(9562):643-56. PubMed PMID: 17321310.

[6]. Kripke K, Vazzano A, Kirungi W, Musinguzi J, Opio A, Ssempebwa R, et al. Modeling the impact of Uganda's safe male circumcision program: Implications for age and regional targeting. PLoS One. 2016 Jul 13;11(7):e0158693. doi: 10.1371/journal.pone.0158693. PubMed PMID: 27410234.

[7]. WHO [Internet]. WHO-UNAIDS HIV Vaccine Initiative. 2012. Available from: http://www.who.int/vaccine_research/diseases/hiv/en/.

[8]. UNAIDS. Global report: Report on Global AIDS Epidemic. New York: USA; 2012

[9]. UN-HABITAT. UN-Habitat Country Programme Document 2016 - 2021 Uganda. UN-Habitat: ISBN: 978-92-1-132706-9; 2016

[10]. WHO [Internet]. Uganda releases preliminary results of the 2016 Uganda population HIV impact assessment. 2017 [cited 2017 Mar 3]. Available from: https://www.afro.who.int/news.

[11]. AVERT [Internet]. HIV/AIDS in Uganda 2016. 2017 [cited 2017 Mar 3]. Available from: www.avert.org

[12]. Yebra G, Ragonnet-Cronin M, Ssemwanga D, Parry CM, Logue CH, Cane PA, et al. Analysis of the history and spread of HIV-1 in Uganda using phylodynamics. J Gen Virol. 2015 Jul;96(Pt 7):1890-8. doi: 10.1099/ vir.0.000107. PubMed PMID: 25724670.

[13]. Uganda AIDS Commission. National HIV and AIDS Strategic Plan. Ministry of Health. Kampala: Uganda; 2012.

[14]. Ministry of Health. Uganda AIDS Indicator Survey. Kampala: Uganda; 2011. 
[15]. Kong X, Ssekasanvu J, Kigozi G, Lutalo T, Nalugoda F, Serwadda D, et al. Male circumcision coverage, knowledge, and attitudes after 4-years of program scale-up in Rakai, Uganda. AIDS Behav. 2014 May;18(5):880-4. doi: 10.1007/s10461-014-0740-0. PubMed PMID: 24633740.

[16]. Moses S, Bradley JE, Nagelkerke NJ, Ronald AR, Ndinya-Achola JO, Plummer FA. Geographical patterns of male circumcision practices in Africa: association with HIV seroprevalence. Int J Epidemiol. 1990 Sep;19(3):693-7. PubMed PMID: 2262266.

[17]. Atashili J. Adult male circumcision to prevent HIV?. Int J Infect Dis. 2006 May;10(3):202-5. PubMed PMID: 16412681.

[18]. Peltzer K, Niang CI, Muula AS, Bowa K, Okeke L, Boiro H, et al. Male circumcision, gender and HIV prevention in sub-Saharan Africa: a (social science) research agenda. SAHARA J. 2007 Nov;4(3):658-67. PubMed PMID: 18185893.

[19]. WHO. Male Circumcision: Global Trends and Determinants of Prevalence, Safety and Acceptability. Geneva: Switzerland; 2009.

[20]. Williams BG, Lloyd-Smith JO, Gouws E, Hankins C, Getz WM, Hargrove J, et al. The potential impact of male circumcision on HIV in Sub-Saharan Africa. PLoS Med. 2006 Jul;3(7):e262. PubMed PMID: 16822094.

[21]. Kenya Demographic Health Survey. Ministry of Health. Nairobi: Kenya; 2014

[22]. Rennie S, Muula AS, Westreich D. Male circumcision and HIV prevention: ethical, medical and public health tradeoffs in low-income countries. J Med Ethics. 2007 Jun;33(6):357-61. PubMed PMID: 17526688.

[23]. Moses S, Plummer FA, Bradley JE, Ndinya-Achola JO, Nagelkerke NJ, Ronald AR. The association between lack of male circumcision and risk for HIV infection: a review of the epidemiological data. Sex Transm Dis. 1994 JulAug;21(4):201-10. PubMed PMID: 7974070.

[24]. Bailey RC, Plummer FA, Moses S. Male circumcision and HIV prevention: current knowledge and future research directions. Lancet Infect Dis. 2001 Nov;1(4):223-31. PubMed PMID: 11871509.

[25]. Wilson D, de Beyer J. Male Circumcision: Evidence and Implications. 2006 [cited 2017 Feb 21]. Available from: http:// siteresources.worldbank.org.

[26]. Bailey RC, Egesah O. Assessment of Clinical and Traditional Male Circumcision Services in Bungoma District, Kenya: Complications Rates and Operational Needs. Special Report. 2006.

[27]. Wambura M, Mwanga J, Mosha J, Mshana G, Mosha F, Changalucha J. Situation analysis for male circumcision in Tanzania. 2009.
[28]. Quinn TC. Circumcision and HIV transmission. Curr Opin Infect Dis. 2007 Feb;20(1):33-8. PubMed PMID: 17197879.

[29]. Rasool R, Syed SA, Siddiqi MA. Male circumcision: Its role in HIV prevention. IIOAB J. 2011;2(5):19-24.

[30]. Westercamp N, Bailey RC. Acceptability of male circumcision for prevention of HIV/AIDS in sub-Saharan Africa: a review. AIDS Behav. 2007 May;11(3):341-55. PubMed PMID: 17053855.

[31]. Weiss HA, Quigley MA, Hayes RJ. Male circumcision and risk of HIV infection in sub-Saharan Africa: a systematic review and meta-analysis. AIDS. 2000 Oct 20;14(15):2361-70. PubMed PMID: 11089625.

[32]. Bailey RC, Muga R, Poulussen R, Abicht H. The acceptability of male circumcision to reduce HIV infections in Nyanza Province, Kenya. AIDS Care. 2002 Feb;14(1):27-40. PubMed PMID: 11798403.

[33]. Kebaabetswe P, Lockman S, Mogwe S, Mandevu R, Thior I, Essex M, et al. Male circumcision: an acceptable strategy for HIV prevention in Botswana. Sex Transm Infect. 2003 Jun;79(3):214-9. PubMed PMID: 12794204.

[34]. Uganda Bureau of Statistics. Statistical Abstract: Kampala. Uganda: UBOS; 2016.

[35]. Christensen, L. B. Johnson, R. B., \& Turner, L. A. (Eds). (2011). Research Methods, Design and Analysis (11th ed). Boston: Pearson Education.

[36]. Kish L. Survey Sampling. New York: John Wiley and Sons, Inc; 1965.

[37]. Rossi PH, Lipsey MW, Freeman HE. Evaluation: A systematic approach. Sage publications; 2003 Oct 14.

[38]. Chikutsa A. Contextualizing the adoption of $\mathrm{MC}$ as an HIV prevention strategy in Zimbabwe. 2011 [cited 2016 Dec 17]. Available from: http:// uaps2011.princeton.edu/papers/110446.

[39]. Mattson CL, Bailey RC, Muga R, Poulussen R, Onyango T. Acceptability of male circumcision and predictors of circumcision preference among men and women in Nyanza Province, Kenya. AIDS Care. 2005 Feb;17(2):18294. PubMed PMID: 15763713.

[40]. Scott BE, Weiss HA, Viljoen JI. The acceptability of male circumcision as an HIV intervention among a rural Zulu population, Kwazulu-Natal, South Africa. AIDS Care. 2005 Apr;17(3):304-13. PubMed PMID: 15832878.

[41]. Risser JM, Risser WL, Eissa MA, Cromwell PF, Barratt MS, Bortot A. Selfassessment of circumcision status by adolescents. Am J Epidemiol. 2004 Jun 1;159(11):1095-7. PubMed PMID: 15155294. 